\title{
Size and Cell Type Dependent Uptake of Silica Nanoparticles
}

I-Lun Hsiao ${ }^{1,3}$, Annika Mareike Gramatke', Rastko Joksimovic ${ }^{2}$, Marek Sokolowski ${ }^{2}$, Michael Gradzielski ${ }^{2}$ and Andrea Haase ${ }^{1 *}$

${ }^{1}$ Federal Institute for Risk Assessment (BfR), Department Chemicals and Product Safety, Berlin, Germany

${ }^{2}$ Technische Universität Berlin, Department of Chemistry, Physical Chemistry/ Molecular Material Sciences, Berlin, Germany

${ }^{3}$ Department of Biomedical Engineering and Environmental Sciences, National Tsing Hua University, Hsinchu, Taiwan

\begin{abstract}
As silica nanoparticles $\left(\mathrm{SiO}_{2} \mathrm{NP}\right)$ gain increasing interest for medical applications it is important to understand their potential adverse effects for humans. Here we prepared well-defined core-shell fluorescently labelled $\mathrm{SiO}_{2} \mathrm{NP}$ of 15, 60 and $200 \mathrm{~nm}$ diameter and analyzed their cytotoxicity in THP-1 derived macrophages, A549 epithelial cells, HaCaT keratinocytes and NRK-52E kidney cells. We observed a size-dependent cytotoxicity in all cell types in serumfree conditions. HaCaT cells were least and macrophages or lung derived A549 cells were highly sensitive towards $\mathrm{SiO}_{2} \mathrm{NP}$ treatment. Differences in cytotoxicity could be correlated with different uptake rates. By using flow cytometry and confocal microscopy we quantified the uptake. Furthermore we used specific inhibitors for clathrin- and caveolinmediated endocytosis to elucidate the uptake mechanisms, which were found to be dependent on the NP size and the cell type. Clathrin-mediated endocytosis was involved in the uptake of $\mathrm{SiO}_{2} \mathrm{NP}$ of all sizes and was the major pathway for $60 \mathrm{~nm}$ or $200 \mathrm{~nm} \mathrm{SiO}{ }_{2}$ NP. Caveolin-mediated endocytosis contributed to the uptake of 60 and $200 \mathrm{~nm} \mathrm{SiO}{ }_{2} \mathrm{NP}$ in THP-1 macrophages but only to uptake of $200 \mathrm{~nm} \mathrm{SiO} 2 \mathrm{NP}$ in A549. However, in the presence of serum all $\mathrm{SiO}_{2} \mathrm{NP}^{2}$ were non-toxic. The presence of serum furthermore could alter the uptake mechanism. In summary, this study demonstrates size- and cell type dependent differences in $\mathrm{SiO}_{2} \mathrm{NP}$ uptake and toxicity.
\end{abstract}

Keywords: Silica nanoparticles; Core-shell nanoparticles; Uptake mechanisms; Endocytosis; Cytotoxicity

Abbreviations: AAS: Atomic Absorption Spectroscopy, APTS: (3-Aminopropyl)- triethoxysilane, CLSM: Confocal Laser Scanning Microscopy, CME: Clathrin-mediated Endocytosis, DLS: Dynamic Light Scattering, DMEM: Dulbecco's Modified Eagle's Medium, DMSO: Dimethyl Sulfoxide, FACS: Flow Cytometry; FCS: Foetal Calf Serum, HBSS: Hank's Balanced Salt Solution; ICP-MS: Inductively Coupled Plasma Mass Spectrometry; ICP-OES: Inductively Coupled Plasma Optical Emission Spectrometry; LacCer: Lactosylceramide; NM: Nanomaterials; NP: Nanoparticles; NRK: Normal Rat Kidney; PBS: Phosphate Buffered Saline; PFA: Paraformaldehyde; PMA: phorbol12-myristate-13-acetate; ROS: Reactive Oxygen Species; $\mathrm{SiO}_{2} \mathrm{NP}$ : Silica Nanoparticles; TEOS: Tetraethoxysilane; TEM: Transmission Electron Microscopy

\section{Introduction}

Nanomaterials (NM) are gaining increasing interest for various fields of application. They are used in the medical sector, in consumer products, for building materials, in computer technology or for waste remediation. By yearly production volumes and by number of products, silica nanoparticles $\left(\mathrm{SiO}_{2} \mathrm{NP}\right)$ belong to the highest commercialized $\mathrm{NP}$, ranked as number 4 by the project of emerging nanotechnology [1]. $\mathrm{SiO}_{2} \mathrm{NP}$ are frequently used in consumer products and in nanocomposites, where they can act as a binder in ceramics or increase the scratching resistance of varnishes [1-3]. Furthermore, they gained huge interest in medicine for gene or drug delivery, in cancer therapy and for imaging purposes [4]. $\mathrm{SiO}_{2}$ are very versatile NP. They can be easily synthesized in various well defined sizes and can be easily surface modified. Thus, they can be labeled with different dyes for imaging purposes or with antibodies for specific targeting [5,6]. Mesoporous variants can be loaded with drugs. Due to their increasing use and the various interesting possible future applications it is important to analyze putative hazards of $\mathrm{SiO}_{2} \mathrm{NP}$ for humans.

In principle several uptake routes need to be considered, i.e dermal, intestinal, inhalative or for medical applications also intravenous injections. It is known that after systemic uptake, NP can be transported to secondary organs such as kidney, liver, spleen and eventually also to the brain [7]. In short term inhalation studies nonsurface modified amorphous $\mathrm{SiO}_{2}$ was able to induce slight or marked inflammation $[8,9]$. Pulmonary inflammation and lung tissue damage was also detected in instillation studies in mice [10]. Skin penetration of $\mathrm{SiO}_{2} \mathrm{NP}$ was detected in vivo and in vitro $[11,12]$. After three days of topical exposure to the ear skin in mice $\mathrm{SiO}_{2} \mathrm{NP}$ were detected inside Langerhans cells and in the cervical lymph nodes [11]. In human skin explants they could be detected in epidermal and dendritic cells [12]. In an oral study elevated silica levels were found in the spleen after $84 \mathrm{~d}$ in the highest dose group [13]. After iv injection $\mathrm{SiO}_{2} \mathrm{NP}$ were found in the muscle, bone, skin, liver, lung and spleen $[14,15]$ with detectable changes in histopathology for liver, spleen and lung tissues [15].

Toxicity of $\mathrm{SiO}_{2} \mathrm{NP}$ was studied in different cell types. $\mathrm{SiO}_{2} \mathrm{NP}$ may induce cytotoxicity or apoptosis and lead to inflammation, DNA damage, or lipid peroxidation in various cell lines [16-20]. These adverse effects could be mediated by oxidative stress or/and the activation of stress-related signalling pathways $[21,22]$. The toxicity appears to be dependent on NP size and surface [17,23-26]. For instance, Li et al. have demonstrated that $\mathrm{SiO}_{2} \mathrm{NP}$ with diameters of $19,43,68$ and 498 $\mathrm{nm}$ cause cytotoxicity, increased reactive oxygen species (ROS) level, DNA damage and cell cycle arrest in HepG2 cells in a size-dependent manner [23]. Other studies also detected size-dependent inflammation $[25,26]$. Furthermore toxicity seems to be dependent on the cell line $[27,28]$. For instance, skin derived HaCaT cells appeared to be more resistant towards $14 \mathrm{~nm} \mathrm{SiO} 2 \mathrm{NP}$ compared to lung derived A549 and

*Corresponding author: Andrea Haase, Max-Dohrn-Str. 8-10, D - 10589 Berlin, Germany, Tel: 49-30-18412-3423; Fax: 49-30-6-18412-3423; E-mail: andrea.haase@bfr.bund.de

Received November 05, 2014; Accepted November 24, 2014; Published December 03, 2014

Citation: Hsiao I, Gramatke AM, Joksimovic R, Sokolowski M, Gradzielski M, et al (2014) Size and Cell Type Dependent Uptake of Silica Nanoparticles. J Nanomed Nanotechnol 5: 248. doi: 10.4172/2157-7439.1000248

Copyright: (c) $2014 \mathrm{Hsiao} \mathrm{I,} \mathrm{et} \mathrm{al.} \mathrm{This} \mathrm{is} \mathrm{an} \mathrm{open-access} \mathrm{article} \mathrm{distributed} \mathrm{under}$ the terms of the Creative Commons Attribution License, which permits unrestricted use, distribution, and reproduction in any medium, provided the original author and source are credited. 
HT29 colon cells [29]. Different forms of $\mathrm{SiO}_{2} \mathrm{NP}$, ie mesoporous, crystalline, or amorphous also show differences in toxicity [30-32]. Crystalline $\mathrm{SiO}_{2}$ induced sustained pulmonary inflammation in in vivo instillation, while the responses to amorphous $\mathrm{SiO}_{2} \mathrm{NP}$ were reversible [33]. Intraperitoneal application of mesoporous but not of amorphous colloid silica $\mathrm{SiO}_{2}$ led to systemic immune responses in mice [34]. Taken together there is various evidence, that $\mathrm{SiO}_{2} \mathrm{NP}$ may be taken up through various routes, reach secondary target organs and may also lead to adverse effects. The uptake and the toxicity mechanisms are not understood in detail. However, in particular for medical applications it is important to understand and to control the uptake of the NP as this may critically affect the drug efficiency.

For this purpose the uptake into various cells and tissues needs to be quantified. This may be done via inductively coupled plasma mass spectrometry (ICP-MS), optical emission spectroscopy (ICP-OES), or atomic absorption spectroscopy (AAS) [35-38]. However, none of these methods is able to determine NP localization. For this purpose many studies use fluorescently labeled $\mathrm{SiO}_{2} \mathrm{NP}$ [22,25,27,28,39-43]. By combining flow cytometry and confocal microscopy it is possible to get time and space resolved semi-quantitative and qualitative uptake information [42]. Furthermore, it is feasible to perform quantification in flow cytometry after determining average fluorescent intensity per particle. A size-, time- and cell type-dependent uptake has been shown for fluorescent-labeled $\mathrm{SiO}_{2} \mathrm{NP}$ in several studies [22,27,40,42,43]. Uptake mechanisms are less well analyzed. It is known that endocytosis is involved in uptake of $\mathrm{SiO}_{2} \mathrm{NP}$ in HepG2 [40], THP-1 [22], A549 [22,42], HeLa [43], and NCI-H292 cells [44]. Smaller $\mathrm{SiO}_{2} \mathrm{NP}$ may also translocate in cells via energy independent pathways or even by passive diffusion $[28,43,44]$. Endocytosis can be differentiated into clathrinmediated or caveolin-mediated endocytosis. Clathrin-mediated endocytosis seems to mediate uptake of a wide size range of particles $(55.6 \mathrm{~nm} \sim 600 \mathrm{~nm})$ in different cell types [17,27,40,43], while size range for caveolin-mediated endocytosis is much more limited $[17,43]$. In addition there are also clathrin- and caveolin-independent uptake pathways $[25,41]$.

$\mathrm{NP}$ are altered in biological media for instance by the formation of a so-called protein corona. This will influence the NP uptake and the uptake mechanisms. In the presence of serum $\mathrm{SiO}_{2} \mathrm{NP}$ show a reduced adhesion to cell membrane and a reduced uptake $[45,46]$. Formation of a corona can also increase NP agglomeration $[47,48]$. Recently, there are indications that uptake mechanisms are altered in the presence or absence of a protein corona $[49,50]$.

Unfortunately, nearly all these studies suffer from major drawbacks. Dye-labeled $\mathrm{SiO}_{2} \mathrm{NP}$ may release a certain amount of dye over time by so-called dye leakage [51]. Usually the dye is attached to the surface, which can alter the surface properties and may have a strong influence on the uptake mechanisms on its own [27]. Thus, our motivation was to apply core-shell fluorescently labeled $\mathrm{SiO}_{2} \mathrm{NP}$, which are protected by an additional silica shell. We used three different sizes of this coreshell $\mathrm{SiO}_{2}$ particles (diameters of 15, 60 and $200 \mathrm{~nm}$ ). We analyzed size dependent uptake and uptake mechanisms in four different relevant cell lines representing different uptake routes. Human lung adenocarcinoma epithelial cell line (A549) were used as a lung related cell line and human keratinocyte cell line (HaCaT) as a skin related cell line. THP-1 derived macrophages and rat kidney epithelioid cell line (NRK-52E) are models for important secondary targets. We studied the uptake by flow cytometry and confocal microscopy and used different inhibitors to get insights into the uptake mechanisms. Studies were performed in the presence and absence of serum.

\section{Materials and Methods}

\section{Synthesis of nanoparticles}

Dye-labeled $\mathrm{SiO}_{2} \mathrm{NP}$ with silica coating were prepared in three steps: synthesis of $\mathrm{SiO}_{2} \mathrm{NP}$, labeling with dye and final silica coating. The 60 and $200 \mathrm{~nm} \mathrm{SiO}{ }_{2}$ NP were synthesized as published [52], while $15 \mathrm{~nm}$ particles were from a commercial source (Ludox SM, obtained as a $30 \%$ wt. suspension in $\mathrm{H}_{2} \mathrm{O}$, Sigma-Aldrich, Taufkirchen, Germany). The surface was functionalized with (3-Aminopropyl)-triethoxysilane (APTS, $\geq 98 \%$, Sigma-Aldrich, Taufkirchen, Germany). For labeling Alexa Fluor 488 5-SDP Ester (Invitrogen, Darmstadt, Germany) was dissolved in ethanol $\left(1.5 \times 10^{-4} \mathrm{~g}^{\text {Alexa }} / \mathrm{g}^{\text {Ethanol }}\right)$, added to the suspension of aminated $\mathrm{SiO}_{2} \mathrm{NP}$, which has been adjusted to $\mathrm{pH} 5$ and left stirring overnight. Alexa-labeled $\mathrm{SiO}_{2}$ dispersions were then adjusted to a $\mathrm{pH}$ of 8-9 before adding lysine and sonicated for $2 \mathrm{~h}$. As a catalyst for the formation of the silica shell 35-45 mg of lysine was added, followed by dropwise addition of $0.08-0.17 \mathrm{~g}$ tetraethoxysilane (TEOS, $\geq 98 \%$, ABCR, Germany) at $60^{\circ} \mathrm{C}$ and reacted overnight. After coating the $\mathrm{SiO}_{2}$ dispersions were dialyzed in water. We confirmed an approximately $1.5 \mathrm{~nm}$ thick layer around the Alexa-labeled $\mathrm{SiO}_{2} \mathrm{NP}$ by dynamic light scattering (DLS) and transmission electron microscopy TEM (Figure S1). Two batches of submicron silica particles were synthesized, both approximately $200 \mathrm{~nm}$. One $(221 \mathrm{~nm})$ was used in toxicity and uptake studies, and another one $(177 \mathrm{~nm})$ was used to study uptake mechanisms. For both batches cytotoxicity and quantification of uptake by flow cytometry has been analyzed.

NP were stable for several month and no dye leakage was detected for up to 6 month (Figure S2). For this purpose NP were depleted by ultracentrifugation and the supernatants have been analysed by fluorescence spectrometry (Perkin Elmer, Rodgau, Germany). For control purposes the NP suspensions as well as pure water has been analysed.

\section{Suspension of nanoparticles}

Suspensions of particles were freshly prepared before each experiment. Stock solutions of $\mathrm{SiO}_{2} \mathrm{NP}$ were first ultrasonicated in an ultrasonication bath (Sonorex, Bandelin, Berlin, Germany) for 5 min while cooled in an ice bath and then diluted to $2.5 \mathrm{mg} / \mathrm{mL}$ in the indicated medium and stirred at $700 \mathrm{rpm}$ for $1 \mathrm{~h}$ at room temperature to achieve optimal dispersion.

\section{Characterization of nanoparticles}

Primary sizes and morphology of $\mathrm{SiO}_{2} \mathrm{NP}$ were measured by transmission electron microscope (TEM,Tecnai G $\mathrm{G}^{2} 20$ S-TWIN, FEI, Oregon, USA) as published elsewhere [52]. The hydrodynamic diameters of $\mathrm{SiO}_{2} \mathrm{NP}$ were examined by dynamic light scattering (DLS) (Zetasizer Nano ZS, Malvern, Herrenberg, Germany) at room temperature. Particles were diluted for DLS measurement to a final concentration of $100 \mu \mathrm{g} / \mathrm{mL}$.

\section{Cell culture}

THP-1 cells (ACC 16 from DSMZ, Braunschweig, Germany) were cultured in RPMI 1640 medium supplemented with $10 \%$ foetal calf serum (FCS), 1\% L-glutamine, 1\% penicillin/streptomycin, 1\% Hepes and $1 \%$ sodium pyruvate. A549 cells (obtained via EU FP7 QualityNano project from UCD, Dublin, Ireland) were cultured in Ham's F12 medium supplemented with 10\% FCS, 1\% L-glutamine and $1 \%$ penicillin/streptomycin. HaCaT cells (CLS Cell Lines Service $\mathrm{GmbH}$, Eppelheim, Germany) were cultured in DMEM medium supplemented with $10 \%$ FCS, $1 \%$ L-glutamine and $1 \%$ penicillin/ 
streptomycin. NRK-52E cells (ACC 199, DSMZ, Braunschweig, Germany) were cultured in Dulbecco's Modified Eagle's high glucose medium (DMEM) supplemented with 10\% FCS, 1\% L-glutamine, $1 \%$ penicillin/streptomycin and $2.5 \%$ Hepes. All cell lines were cultivated at $37^{\circ} \mathrm{C}, 5 \% \mathrm{CO}_{2}$ and with $95 \%$ relative humidity. Phorbol-12-myristate13 -acetate (PMA) at $100 \mathrm{ng} / \mathrm{mL}$ for $24 \mathrm{~h}$ was used to differentiate THP1 cells into macrophages like cells.

\section{Cytotoxicity}

WST-1 cell viability assay was used to evaluate the toxicity of $\mathrm{SiO}_{2} \mathrm{NP}$ according to manufacturer instructions (Roche Diagnostics, Mannheim, Germany). Cells were treated $24 \mathrm{~h}$ after seeding in 96 -well plates with 10, 20 and $50 \mu \mathrm{g} / \mathrm{mL} \mathrm{SiO}_{2} \mathrm{NP}$ for $24 \mathrm{~h}$. As positive control, dimethyl sulfoxide (DMSO) was used (10 $\mu \mathrm{L}$ for THP-1, A549 and NRK-52E cells, $20 \mu \mathrm{L}$ for HaCaT cells). Interfering NP were removed in a table top centrifuge by centrifugation with maximum speed prior to spectrophotometric read-out (TECAN, Switzerland) at $450 \mathrm{~nm}$. Mean values \pm SEM are given from three independent experiments.

\section{Confocal microscopy}

Cells were treated with $\mathrm{SiO}_{2} \mathrm{NP}$ suspensions at $20 \mu \mathrm{g} / \mathrm{mL} 24 \mathrm{~h}$ after seeding $\left(2.5 \times 10^{5}\right.$ cells $\left./ \mathrm{mL}\right)$ on coverslips in 6-well culture plates. After 2 or $24 \mathrm{~h}$ of incubation, cell nuclei were stained by Hoechst 33342 (Life Technologies, Darmstadt, Germany) (100 ng/mL, $5 \mathrm{~min}$ ). $50 \mathrm{nM}$ LysoTracker Red (Life Technologies, Darmstadt, Germany) were added $30 \mathrm{~min}$ before end of treatment. Cells were washed three times with phosphate buffered saline (PBS) and were fixed with $4 \%$ paraformaldehyde (PFA) in PBS (pH 7.4). Images were obtained by confocal laser scanning microscopy (CLSM) system LSM 700 (Carl Zeiss, Göttingen, Germany) with a $63 \times$ oil-immersion objective using $488 \mathrm{~nm}$ laser for Alexa-488, $405 \mathrm{~nm}$ for Hoechst33342 and $555 \mathrm{~nm}$ for LysoTracker Red.

\section{Immunofluorescence}

Cells were seeded as for CLSM analysis. As positive substrates we used BODIPY-LacCer (1 $\mu \mathrm{M}$, Life Technologies, Darmstadt, Germany) for Cavoelin mediated or FITC-Transferrin $(10 \mu \mathrm{g} / \mathrm{mL}$, Life Technologies, Darmstadt, Germany) for Clathrin mediated endocytosis in serum-free medium for $1.5 \mathrm{~h}$. Cells were washed three times with PBS and were fixed with 4\% PFA. For immunofluorescence cells were stained as described elsewhere [53]. Primary antibodies (anti-caveolin or anti-clathrin, New England Biolabs, Frankfurt a.M., Germany) were diluted in HBSS (Hank's balanced salt solution) at 1:200 and applied overnight at $4^{\circ} \mathrm{C}$. Secondary antibody (Alexa-546 goat-anti-rabbit, Life Technologies, Darmstadt, Germany) was diluted 1:200 and applied for $1.5 \mathrm{~h}$ at room temperature. Cells were mounted using Vectashield mounting medium (Linaris GmbH, Dossenheim, Germany).

\section{Flow Cytometric analysis (FACS)}

For FACS analysis $2.5 \times 10^{5}$ cells $/ \mathrm{mL}$ were seeded into 6-well plates for $24 \mathrm{~h}$, then medium was replaced to serum-free medium (if indicated). Cells were exposed to 10,20 and $50 \mu \mathrm{g} / \mathrm{mL} \mathrm{SiO}{ }_{2} \mathrm{NPs}_{\text {for }}$ 2 or $24 \mathrm{~h}$, were washed three times with PBS, detached by $0.05 \%$ trypsin/EDTA (A549, HaCaT and NRK-52E cells) or accutase (THP-1 macrophages), harvested by centrifugation, washed again with PBS and resuspended in PBS for FACS analysis. The fluorescence of 20,000 cells was detected at FITC channel after excitation at $488 \mathrm{~nm}$ laser using a BD FACSAriaIII (BD biosciences, Heidelberg, Germany).

For studying uptake mechanisms A549 and THP-1 cells were pretreated for $30 \mathrm{~min}$ with 50 or $100 \mu \mathrm{M}$ genistein ( $24 \mathrm{~h}$ or $2 \mathrm{~h}$, respectively),
1 or $2.5 \mu \mathrm{g} / \mathrm{mL}$ filipin III ( $24 \mathrm{~h}$ or $2 \mathrm{~h}$, respectively), and $5 \mu \mathrm{g} / \mathrm{mL}$ chlorpromazine hydrochloride (all from Sigma-Aldrich, Munich, Germany). For potassium-depletion, cells were washed with PBS, with potassium-depletion buffer $(20 \mathrm{mM}$ Hepes $\mathrm{pH} 7.4,140 \mathrm{mM} \mathrm{NaCl}, 1$ $\mathrm{mM} \mathrm{CaCl}, 1 \mathrm{mM} \mathrm{MgCl}, 1 \mathrm{mg} / \mathrm{mL}$ D-glucose) and then incubated in hypotonic buffer $\left(1: 1\right.$ ratio of potassium-depletion buffer and $\left.\mathrm{H}_{2} \mathrm{O}\right)$ for $10 \mathrm{~min}$ at $37^{\circ} \mathrm{C}$ before being transferred to potassium-depletion buffer for $30 \mathrm{~min}$. Controls were untreated cells (for genistein, flipin or chlorpromazine) or cells treated by potassium-depletion buffer supplemented with $10 \mathrm{mM} \mathrm{KCl}$. For inhibitor studies $\mathrm{SiO}_{2} \mathrm{NP}$ were used at $10 \mu \mathrm{g} / \mathrm{mL}$ for 2 and $24 \mathrm{~h}$ of exposure. External fluorescence was quenched using $0.1 \%$ Trypan blue. Uptake was quantified by FACS analysis. BODIPY-LacCer (lactosylceramide complexed to BSA, 0.5 $\mu \mathrm{M})$ and transferrin-fluorescein conjugate $(10 \mu \mathrm{g} / \mathrm{mL})$ were used as control substrates.

\section{Statistics}

All experiments are performed in three independent repeats. Data were presented as means \pm SEM. Analysis was done using GraphPad Prism 5.0.

\section{Results}

\section{Characterization of $\mathrm{SiO}_{2} \mathrm{NP}$}

The $\mathrm{SiO}_{2} \mathrm{NP}$ used in this study contained a silica core, which was labeled with the fluorescent dye Alexa Fluor 488 and then further covered by another silica layer (Figure 1A). NP suspensions were analyzed by dynamic light scattering (DLS) prior to use in water or cell culture medium (Figure 1B and Table 1). TEM was used to confirm shape and size (Figures 1C to 1E). All particles were spherical and uniform in size. Sizes and zeta potentials are listed in Table 1.

In general, our NP were very well dispersed in water and in serumfree cell culture medium. Only the $15 \mathrm{~nm} \mathrm{SiO} 2 \mathrm{NP}$ showed some agglomeration, which can be attributed to the relatively larger surface area and the thereby increased attractive van der Waals interactions. In the presence of serum the 15 and $60 \mathrm{~nm} \mathrm{SiO}{ }_{2}$ NP form agglomerates. The zeta potentials were very similar for all NP.
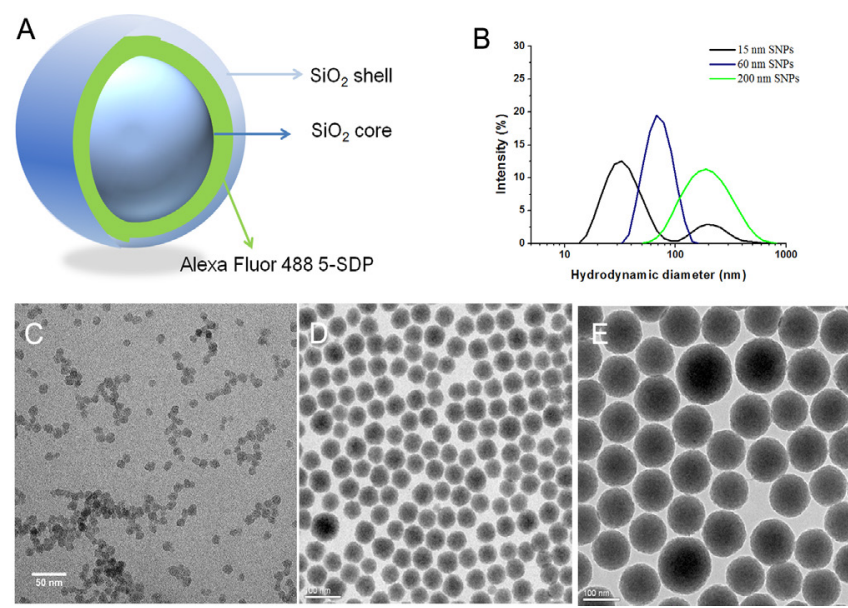

Figure 1: Characterization of the $\mathrm{SiO}_{2}$ NP. Scheme of core-shell fluorescently labeled $\mathrm{SiO}_{2} \mathrm{NP}$ used in this study (A), their hydrodynamic size distribution in water, measured by DLS based on intensity (B), TEM images of $15 \mathrm{~nm}(\mathrm{C}), 60 \mathrm{~nm}(\mathrm{D})$ and $200 \mathrm{~nm}(\mathrm{E}) \mathrm{SiO}_{2} \mathrm{NP}$ 


\begin{tabular}{|c|c|c|c|c|c|c|c|c|}
\hline \multirow[b]{2}{*}{$\mathrm{SiO}_{2} \mathrm{NP}$} & \multicolumn{4}{|c|}{ Hydrodynamic diameter $(\mathrm{nm})^{\mathrm{b}}$} & \multicolumn{3}{|c|}{ Polydispersity index (PdI) } & \multirow{2}{*}{$\begin{array}{c}\text { Zeta }(\mathrm{mV}) \\
\text { water }\end{array}$} \\
\hline & water & RPMIc & $\begin{array}{l}\text { RPMIc }^{c} \\
24 h\end{array}$ & $\begin{array}{c}\text { RPMI } \\
(10 \% \text { FCS })\end{array}$ & water & RPMIc & $\begin{array}{c}\text { RPMI } \\
\text { (10\% FCS) }\end{array}$ & \\
\hline $15 \mathrm{~nm}$ & $42.7 \pm 0.9$ & $41.3 \pm 1.3$ & $226.9 \pm 3.4$ & $70.8 \pm 0.3$ & $0.40 \pm 0.03$ & $0.39 \pm 0.03$ & $0.61 \pm 0.01$ & $-28.1 \pm 0.7$ \\
\hline $60 \mathrm{~nm}$ & $67.9 \pm 0.7$ & $68.8 \pm 1.0$ & $325.2 \pm 6.6$ & $158.2 \pm 3.0$ & $0.05 \pm 0.01$ & $0.05 \pm 0.01$ & $0.48 \pm 0.01$ & $-30.6 \pm 1.2$ \\
\hline $200 \mathrm{~nm}$ & $176.5 \pm 3$ & $124.0 \pm 2$ & $276.5 \pm 3.0$ & $148.1 \pm 2.5$ & $0.19 \pm 0.02$ & $0.02 \pm 0.01$ & $0.34 \pm 0.03$ & $-31.8 \pm 1.6$ \\
\hline
\end{tabular}

aAll measurement were performed at $25^{\circ} \mathrm{C}$ at $100 \mu \mathrm{g} / \mathrm{mL}$

${ }^{b}$ Hydrodynamic diameter was determined as Z-average (\% intensity), which was derived from the cumulant mean of the intensity autocorrelation function.

${ }^{c}$ The hydrodynamic diameters were measured in serum-free RPMI medium.

Table 1: Physicochemical characterization of $\mathrm{SiO}_{2} \mathrm{NP}^{a}$

A

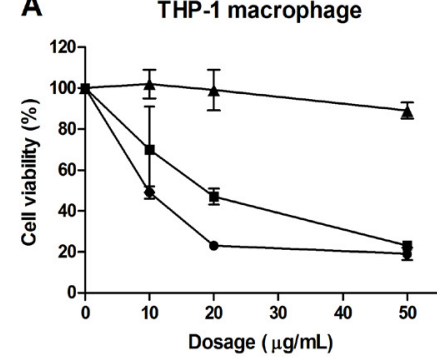

C

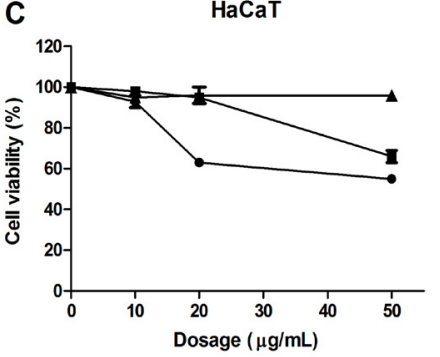

B

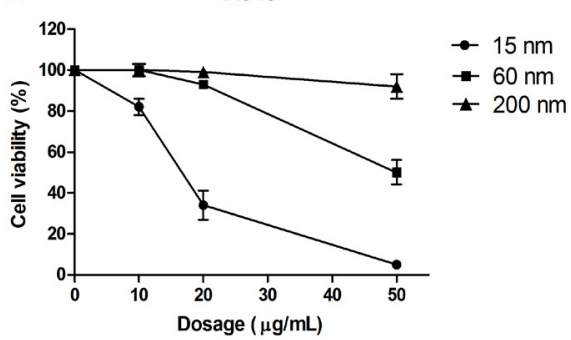

D

NRK-52E

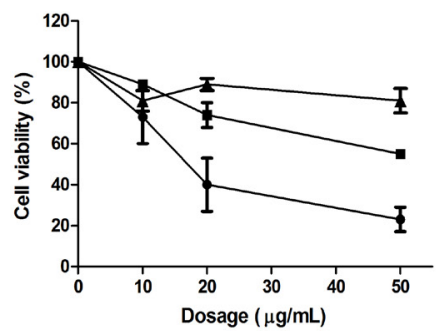

Figure 2: Cytotoxicity of the $\mathrm{SiO}_{2} \mathrm{NP}$ in four different cell lines. Cells were treated with $\mathrm{SiO}_{2} \mathrm{NP}$ at $0,10,20$ and $50 \mu \mathrm{g} / \mathrm{mL}$ for $24 \mathrm{~h}$. Cell viabilities were determined using WST-1 assays and expressed as percentage of untreated control cells. Experiment was repeated in 3 independent runs with using 4 replicas each. Data are given as means \pm SEM for THP-1 macrophages (A), A549 (B), NRK-52E (C) and HaCaT cells (D).

\begin{tabular}{|c|c|c|c|c|}
\hline $\mathbf{S i O}_{\mathbf{2}} \mathbf{N P s}$ & THP-1 macrophage & A549 & HaCaT & NRK-52E \\
\hline $15 \mathrm{~nm}$ & 10 & 15 & - & 15 \\
\hline $60 \mathrm{~nm}$ & 18 & 50 & - & - \\
\hline $200 \mathrm{~nm}$ & - & - & - & - \\
\hline
\end{tabular}

"“" indicates that the $\mathrm{IC}_{50}$ could not be determined as cell viability did not decline to $50 \%$.

Table 2: $\mathrm{IC}_{50}(\mu \mathrm{g} / \mathrm{mL})$ of $\mathrm{SiO}_{2} \mathrm{NP}$ after $24 \mathrm{~h}$ of treatment with four cell lines.

Because of the strong agglomeration of our $\mathrm{SiO}_{2} \mathrm{NP}$ in serumcontaining medium, the main part of this study was done in serum-free medium, i.e prior to NP exposure cells were set to serum-free medium. However, we also included analysis of NP uptake in serum containing cell culture medium and compared this to serum-free conditions.

\section{$\mathrm{SiO}_{2} \mathrm{NP}$ cytotoxicity is dependent on size and on cell type}

Cells were exposed to $\mathrm{SiO}_{2} \mathrm{NP}$ at concentrations of 10,20 and 50 $\mu \mathrm{g} / \mathrm{mL}$ for $24 \mathrm{~h}$ and the cell viability was determined using WST- 1 assay. Data are shown in Figure 2 and summarized in Table 2. The $15 \mathrm{~nm} \mathrm{SiO}$ $\mathrm{NP}$ caused significant cytotoxicity to all tested cell lines. The $60 \mathrm{~nm} \mathrm{SiO}$ NP caused less pronounced cytotoxicity, if applied doses were compared on mass basis. The $200 \mathrm{~nm}$ particles did not display any cytotoxicity in all four cell lines at all applied doses. Most prominent effects towards all NP were observed for THP-1 macrophages (Figure 2A and Table 2), which had an $\mathrm{IC}_{50}$ value of 10 and $18 \mu \mathrm{g} / \mathrm{mL}$ for the $15 \mathrm{~nm}$ and $60 \mathrm{~nm}$
$\mathrm{SiO}_{2}$, respectively. Also in A549 cells (Figure 2B) significant effects were observed, with $\mathrm{IC}_{50}$ values of 15 and $50 \mu \mathrm{g} / \mathrm{mL}$ for $15 \mathrm{~nm}$ and $60 \mathrm{~nm} \mathrm{NP}$, respectively. HaCaT cells were rather insensitive, and an $\mathrm{IC}_{50}$ could not be reached for any size of $\mathrm{SiO}_{2} \mathrm{NP}$ (Figure 2C). NRK-52E cells showed pronounced effects only towards the $15 \mathrm{~nm} \mathrm{SiO}$, the $\mathrm{IC}_{50}$ value was $15 \mu \mathrm{g} / \mathrm{mL}$ (Figure 2D). Interestingly, in serum-containing media no cytotoxicity was observed for all sizes of particles.

Thus, our data confirm a dose-dependent toxicity for $15 \mathrm{~nm}$ and $60 \mathrm{~nm} \mathrm{SiO}{ }_{2}$ NP. If applied doses were compared on mass levels, we observed a clear size dependent effect, which vanished when applied doses were compared on the basis of the total NP surface area (Figure S3), indicating that the toxicity of $\mathrm{SiO}_{2} \mathrm{NP}$ is related to surface area.

Next we wanted to investigate whether the differences in toxicities were related to different uptake rates.

\section{Different cell lines take up different amounts of $\mathrm{SiO}_{2} \mathrm{NP}$}

All cell lines were treated with 15, 60 and $200 \mathrm{~nm} \mathrm{SiO}, \mathrm{NP}_{2}$ at 20 $\mu \mathrm{g} / \mathrm{mL}$ for $2 \mathrm{~h}$ and uptake was analyzed qualitatively with confocal microscopy (Figure 3). THP-1 macrophages rapidly took up $15 \mathrm{~nm}$ and $60 \mathrm{~nm} \mathrm{SiO}{ }_{2} \mathrm{NP}$, already within $2 \mathrm{~h}$. NP were present in small clusters, most likely representing vesicles. The nuclei were free of particles.

A549 also rapidly took up $15 \mathrm{~nm}$ and $60 \mathrm{~nm}$ particles, particles are 


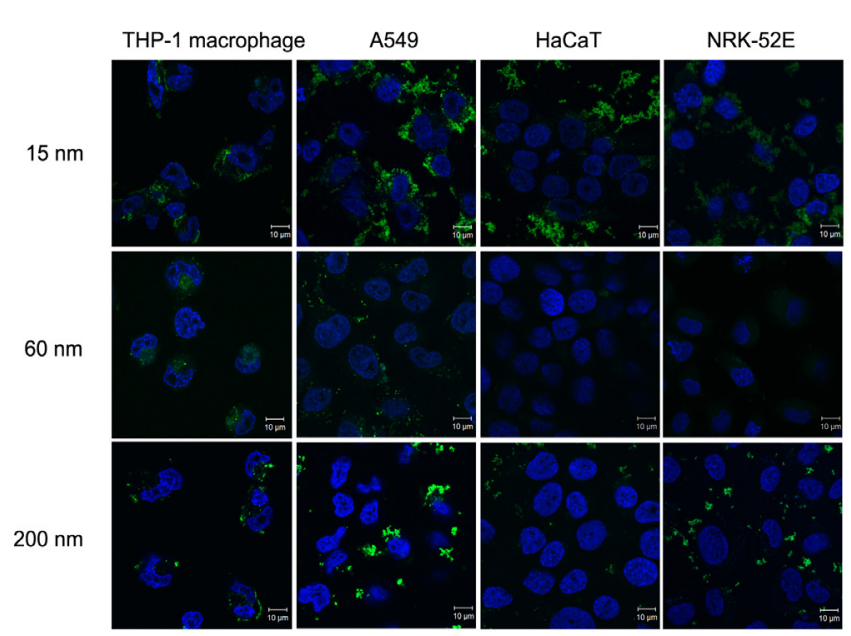

Figure 3: Uptake of $\mathrm{SiO}_{2} \mathrm{NP}$ assessed by confocal imaging. Cells were treated with 15, 60 or $200 \mathrm{~nm}$ silica particles at $20 \mu \mathrm{g} / \mathrm{mL}$ for $2 \mathrm{~h}$. Particles are depicted in green (Alexa 488) and nuclei are blue (Hoechst 33342). Uptake was analyzed in THP-1 macrophages, A549, NRK-52E and HaCaT cells.

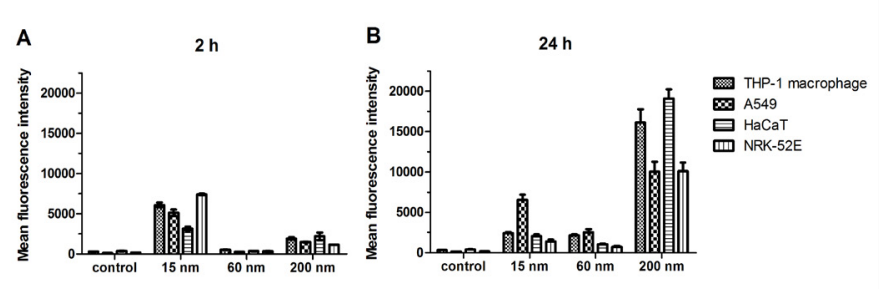

Figure 4: Quantification of cellular uptake using flow cytometry. Cells were treated with 15,60 or $200 \mathrm{~nm} \mathrm{SiO}{ }_{2} \mathrm{NP}$ at $20 \mu \mathrm{g} / \mathrm{mL}$ for either $2 \mathrm{~h}(\mathrm{~A})$ or $24 \mathrm{~h}(\mathrm{~B})$. Uptake was quantified using flow cytometry as mean fluorescence intensities of the cells. Data are presented as means \pm SEM of at least three independent experiments.

visible in clusters inside the cytoplasm already after $2 \mathrm{~h}$. In contrast, NRK-52E cells rapidly took up only $15 \mathrm{~nm}$ but not $60 \mathrm{~nm} \mathrm{SiO}{ }_{2}$ NP. In $\mathrm{HaCaT}$ cells $15 \mathrm{~nm}$ and $60 \mathrm{~nm} \mathrm{\textrm {SiO } _ { 2 }} \mathrm{NP}$ were localized clearly outside the cells after $2 \mathrm{~h}$ treatment (Figure 3), only after $24 \mathrm{~h}$ treatment $\mathrm{SiO}_{2} \mathrm{NP}$ was found inside cells (Figure S4). In all cell lines, the $200 \mathrm{~nm}$ particles hardly entered the cells after $2 \mathrm{~h}$, but many of them attached to cell surface and were thus visible directly on the outer side of cell membrane. For all sizes of $\mathrm{SiO}_{2} \mathrm{NP}$ uptake was confirmed after $24 \mathrm{~h}$ treatment. In no case we found evidence that $\mathrm{SiO}_{2} \mathrm{NP}$ can be transported into the cell nuclei.

We then quantified uptake in all cell lines after $2 \mathrm{~h}$ (Figure $4 \mathrm{~A}$ ) or $24 \mathrm{~h}$ (Figure 4B) incubation using flow cytometry. For $60 \mathrm{~nm}$ and 200 $\mathrm{nm} \mathrm{SiO} 2 \mathrm{NP}$ the uptake profiles to all four cell lines were clearly timedependent. However, the results for the $15 \mathrm{~nm} \mathrm{SiO} 2 \mathrm{NP}$ can be analyzed only after $24 \mathrm{~h}$ as the analysis after $2 \mathrm{~h}$ is confounded from extracellularly attached NP. For the $15 \mathrm{~nm} \mathrm{SiO} 2 \mathrm{NP}$ we therefore only quantified the uptake after $24 \mathrm{~h}$, where we confirmed by confocal microscopy that the NP were clearly inside the cells and not attached to cell surfaces any more. For further studies we decided to apply a quencher, which allowed us to quantify intracellular fluorescence only.

After $24 \mathrm{~h}$ incubation we observe a dose-dependent uptake in all four cell lines by flow cytometry (Figure 5). There is a clear dose

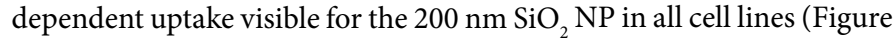

5C). For $60 \mathrm{~nm} \mathrm{SiO} 2 \mathrm{NP}$ this dose dependent uptake was also observed for A549, HaCaT and NRK-52E cells (Figure 5B). However, in THP-1 macrophages $60 \mathrm{~nm} \mathrm{SiO}{ }_{2} \mathrm{NP}$ are already exerting a significant toxicity at $20 \mu \mathrm{g} / \mathrm{mL}$. For the same reason dose-dependent cellular uptake analysis was confounded for $15 \mathrm{~nm} \mathrm{SiO} \mathrm{NP}_{2}$ in THP-1 and A549 cells (Figure 5A).

Using flow cytometry, we again could confirm that indeed THP-1 macrophages and A549 are taking up higher amounts of NP compared to HaCaT and NRK-52E cells. Thus, the amounts taken up correlate very well with the results of the toxicity study (compare results in Figures 2 and 5). Surprisingly, for the $200 \mathrm{~nm} \mathrm{SiO} 2$ NP the differences in uptake between the various cell lines were not as high. This could be an indication that the uptake mechanism for $200 \mathrm{~nm} \mathrm{NP}$ is be different compared to uptake mechanisms for 15 or $60 \mathrm{~nm} \mathrm{NP}$.
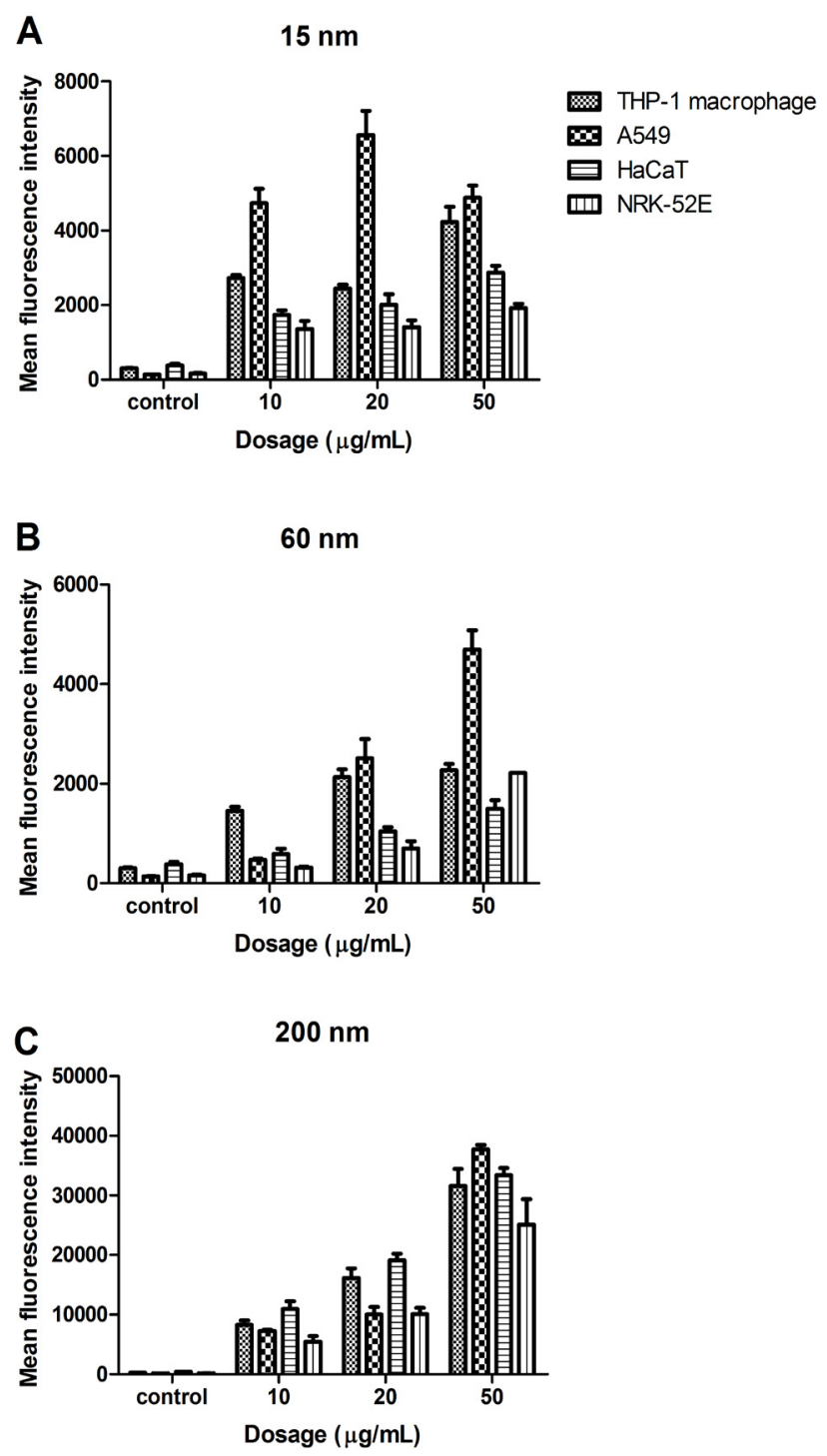

Figure 5: Dose dependent quantification of cellular uptake using flow cytometry. Cells were treated with $0,10,20$ and $50 \mu \mathrm{g} / \mathrm{mL}$ of $15 \mathrm{~nm}(\mathrm{~A}), 60$ $\mathrm{nm}(\mathrm{B})$ or $200 \mathrm{~nm}$ (C) $\mathrm{SiO}_{2}$ NP for $24 \mathrm{~h}$ in THP-1 macrophages, A549, NRK$52 \mathrm{E}$ and $\mathrm{HaCaT}$ cells. Uptake was quantified using flow cytometry as mean fluorescence intensities of the cells. Data are presented as means \pm SEM of at least three independent experiments. 
A
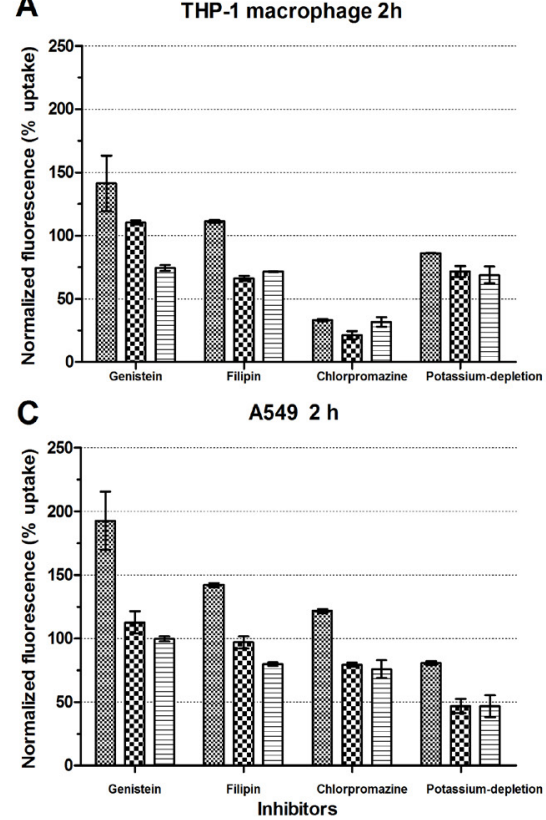

B
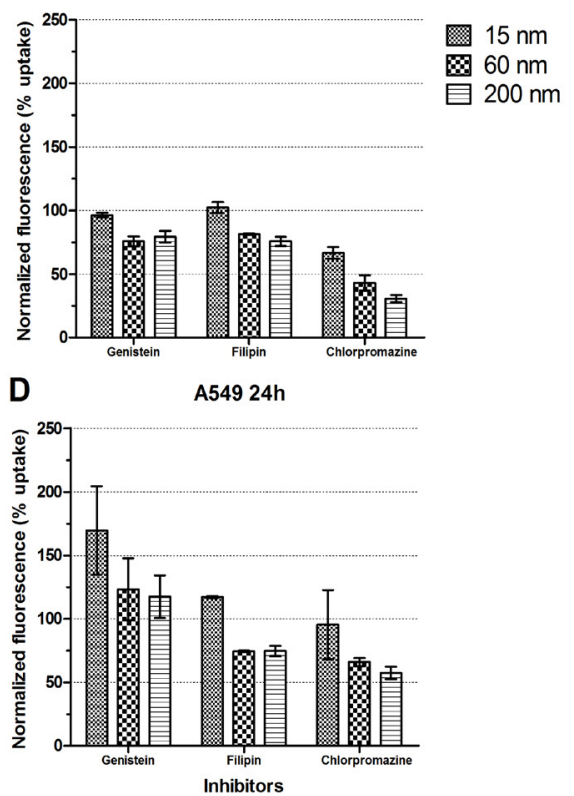

Figure 6: Analysis of uptake mechanisms using different inhibitors. Cells were pretreated with various inhibitors, Genistein, Filipin and Chlorpromazine, for $30 \mathrm{~min}$, followed by exposure to $\mathrm{SiO}_{2} \mathrm{NP}$ in THP-1 macrophages (A and B) and A549 (C and D) cells for either $2 \mathrm{~h}(\mathrm{~A}$ and $\mathrm{C})$ or $24 \mathrm{~h}$ (B and D). The uptake was quantified using flow cytometry as mean fluorescence intensities of the cells. Given are means \pm SEM of 2 independent experiments, each with 3 replicas. The normalized fluorescence (\% uptake) was calculated by dividing the $\mathrm{SiO}_{2} \mathrm{NP}$ fluorescence in the presence of inhibitor by the fluorescence of controls without inhibitors.

In the confocal images we have seen that the $\mathrm{SiO}_{2} \mathrm{NP}$ were not free in cytoplasm, but rather distinctly localized, most likely inside vesicles. We analyzed whether those vesicles represent lysosomes by using LysoTracker Red at different time points, $0.5,2,5$ and $24 \mathrm{~h}$ after adding the NP. After $24 \mathrm{~h}$ we observed a significant co-localization between $15 \mathrm{~nm} \mathrm{SiO} 2 \mathrm{NP}$ and the lysosomal marker (Figure S5). This was not observed at earlier time points.

\section{Size and cell type dependent uptake mechanisms for $\mathrm{SiO}_{2} \mathrm{NP}$}

To further elucidate the uptake mechanisms we used specific inhibitors for clathrin-mediated and caveolin-mediated endocytosis. Genistein, which is a tyrosine kinase inhibitor, and filipin, which acts on cholesterol, were used as inhibitors to block the caveolin-mediated endocytosis. Chlorpromazine, a Rho GTPase inhibitor, and potassiumdepletion, which is acting via clathrin removal, were used to inhibit the clathrin-mediated endocytosis. For that purpose we focused on THP-1 macrophages and A549 cells as they took up highest amounts of $\mathrm{SiO}_{2}$ NP.

Prior to the experiment we carefully analyzed the cytotoxicity of the inhibitors after 2 and $24 \mathrm{~h}$ (Figures S6A-S6D) and used only sub-cytotoxic doses (cell viability higher than $80 \%$ ). Potassium-depletion was only tolerated for $2 \mathrm{~h}$. Furthermore we used fluorescent substrates to confirm the effect of the inhibitors at the applied doses. For that purpose we used BODIPY-LacCer as a substrate for caveolin-mediated endocytosis and transferrin-fluoresceine for clathrin-mediated endocytosis. We analyzed the preferential uptake of transferrin by clathrin- and LacCer by caveolin-mediated endocytosis via immunostaining (Figure S7) and by applying specific inhibitors for the endocytotic pathway (Figure S8). The caveolin-mediated endocytosis could be blocked by genistein and filipin after 2 and $24 \mathrm{~h}$ in THP-1 by $10-20 \%$ and in A549 by $20-30 \%$
(Figure S8A). In A549 cells genistein did only reduce the uptake after $2 \mathrm{~h}$ but not after $24 \mathrm{~h}$ treatment. The clathrin-mediated uptake was blocked by chlorpromazine in THP- 1 macrophages by approx. $40 \%$ at 2 and 24 h. In A549 cells chlorpromazine did not have any effect (Figure S8B). In A549 cells we also analyzed the uptake of clathrin and LacCer in the presence of serum (Figure S8C). The efficiency of potassium-depletion on the uptake of transferrin-fluoresceine was checked by confocal microscopy (Figure S9). With the 3D images, it is clear that potassiumdepletion indeed significantly reduced the uptake of transferrin. After potassium-depletion transferrin-fluorescein is mainly attached to the cell membrane but was not taken up. Thus, we could confirm that indeed the inhibitors used here did suppress the respective pathways to a certain extent. A full blockage was not observed and was also not expected.

In THP-1 macrophages caveolin specific inhibitors had no effect on the uptake of $15 \mathrm{~nm} \mathrm{SiO}$ NP. Filipin could decrease the uptake of the 60 and $200 \mathrm{~nm} \mathrm{SiO}_{2}$ after $2 \mathrm{~h}$ and $24 \mathrm{~h}$ (Figures 6A and 6B). In contrast, clathrin specific inhibitors could decrease the uptake for all three sizes of $\mathrm{SiO}_{2} \mathrm{NP}$. After having applied chlorpromazine for $24 \mathrm{~h}$ the uptake was decreased by $70 \%$ for the $200 \mathrm{~nm}$ particles, by $58 \%$ for $60 \mathrm{~nm} \mathrm{SiO}, \mathrm{NP}$ and only by $33 \%$ for $15 \mathrm{~nm} \mathrm{SiO}{ }_{2} \mathrm{NP}$ (Figure 6B). The uptake mechanism seems to be dependent on NP size.

In $\mathrm{A} 549$ cells the effects of the inhibitors were slightly different (Figures 6C and 6D). For the $15 \mathrm{~nm} \mathrm{SiO}$ the results were comparable to THP-1 macrophages. The inhibitors of the caveolin-mediated endocytosis had no effect on the uptake of the $15 \mathrm{~nm} \mathrm{NP}$ but the potassium depletion could reduce the uptake by $19 \%$. For $60 \mathrm{~nm} \mathrm{SiO}$ NP the inhibitors of the caveolin-mediated pathway had no effect in A549 cells after $2 \mathrm{~h}$, which is in clear contrast to the results in THP-1 macrophages. However, after $24 \mathrm{~h}$ filipin could inhibit the uptake of 


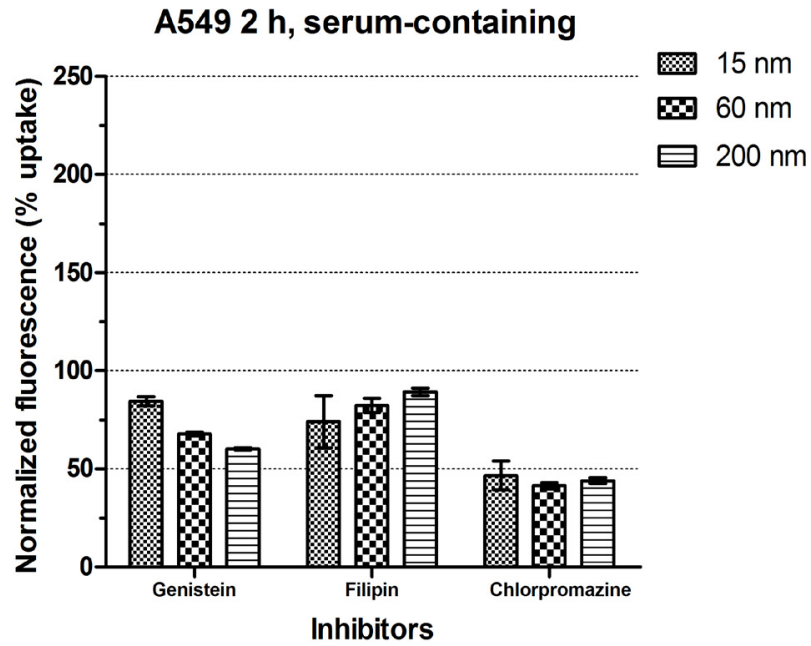

Figure 7: Analysis of uptake mechanisms using different inhibitors in A549 cells in the presence of serum. Cells were pretreated with various inhibitors, Genistein, Filipin and Chlorpromazine, for $30 \mathrm{~min}$, followed by $2 \mathrm{~h}$ exposure to $\mathrm{SiO}$ NP. Given are means \pm SEM of 2 independent experiments, each with 3 replicates. The normalized fluorescence $(\%$ uptake) were calculated by dividing the $\mathrm{SiO}_{2} \mathrm{NP}$ fluoresence in the presence of inhibitor by the fluorescence of controls without inhibitors.

the $60 \mathrm{~nm}$ in A549 cells by $26 \%$, which is similar to the result in THP-1 macrophages. Like in THP-1 cells, all inhibitors could block the uptake of the $200 \mathrm{~nm}$ particles.

These results indicate that the uptake mechanisms seem to be dependent in the cell type.

Finally, we investigated the uptake mechanisms also in the presence of serum in A549 cells (Figure 7). Firstly we observed differences in the total amount, which is taken up. At the same dosage $(10 \mu \mathrm{g} / \mathrm{mL})$, much less $\mathrm{SiO}_{2} \mathrm{NP}$ could be internalized into A549 cells in the presence of serum compared to serum free conditions (data not shown). In order to analyze the effects of the various inhibitors we had to increase the applied doses under serum containing conditions for all sizes to $100 \mu \mathrm{g} / \mathrm{mL}$. However, no significant cytotoxicity was observed in serum-containing medium for all applied doses (Figure S10). The results revealed that for all particles all used inhibitors, i.e genistein, filipin and chlorpromazine, could inhibit the uptake significantly. The caveolin specific inhibitors reduced the uptake by $20-40 \%$ while the clathrin specific chlorpromazine reduced the uptake by more than $50 \%$. In addition we did not observe size- dependent differences in serum containing medium. However, when interpreting these results one needs to consider that in serum containing medium the $\mathrm{SiO}_{2} \mathrm{NP}$ (in particular the 15 or $60 \mathrm{~nm} \mathrm{NP}$ ) are significantly agglomerated such that final agglomerate sizes are very comparable for all three primary particle sizes. As the $200 \mathrm{~nm} \mathrm{SiO}_{2} \mathrm{NP}$ are hardly agglomerated we focused our comparison of serum containing vs. serum free medium on the $200 \mathrm{~nm} \mathrm{SiO}{ }_{2}$ NP. In serum containing medium, the treatment with chlorpromazine blocked the uptake of the $200 \mathrm{~nm} \mathrm{SiO} 2 \mathrm{NP}$ drastically. In serum-free medium in A549 cells in contrast all three inhibitors had a rather similar effect. This indicates that the uptake of the $200 \mathrm{~nm}$ particles in the presence of serum seems to be more specific, predominantly via the clathrin-mediated pathway.

\section{Discussion}

The cytotoxic effects of $\mathrm{SiO}_{2} \mathrm{NP}(15,60,200 \mathrm{~nm})$ were investigated in four different cell lines, A549, HaCaT, THP-1 derived macrophages and NRK-52E, which are representing different possible target organs (lung, skin, immune system and kidney). Most prominent effects were observed after exposure to $15 \mathrm{~nm} \mathrm{SiO}{ }_{2} \mathrm{NP}$. The $60 \mathrm{~nm} \mathrm{SiO} \mathrm{NP}_{2}$ caused less pronounced cytotoxicity and the $200 \mathrm{~nm}$ particles were not toxic at all. If applied doses are compared on mass levels, we observed a clear size dependent toxicity as also described by others $[23,54,55]$. Cytotoxicty, in particular for small $\mathrm{SiO}_{2} \mathrm{NP}$, has been described already in various cell types, including lung cancer cells, myocardial cells or human endothelial cells [55-57]. Smaller NP have a larger specific surface (ie ratio of surface area to volume) leading to a higher surface reactivity $[7,58,59]$. It has been published that silica surfaces can generate $\cdot \mathrm{OH}$ radical, which may then cause cellular damage $[31,60]$. This may explain the higher toxicity observed for the small $\mathrm{SiO}_{2}$ NP. Furthermore, for the 15 and $60 \mathrm{~nm} \mathrm{SiO}{ }_{2} \mathrm{NP}$ we detected a dose-dependent cytotoxicity as also observed by others [56,57].

Toxicity furthermore was dependent on the cell line. THP-1 macrophages were the most sensitive cell line followed by A549 cells. In contrast, $\mathrm{HaCaT}$ cells were rather tolerant. This may be explained by different physiological functions and correlated well to differences in uptake. Kroll et al. studied 23 NP in ten different cell lines [61] and also reported differences in the sensitivity of the cell lines. However, $\mathrm{SiO}_{2} \mathrm{NP}$ were not included in that study. Other studies using $\mathrm{SiO}_{2} \mathrm{NP}$ already found that epithelial cells or tumor cells were less sensitive compared to phagocytic cells or fibroblasts [62-64].

Interestingly the particle surface seems to be critical for explaining the toxicity of $\mathrm{SiO}_{2}$ NP. Here we could confirm that differences in toxicity are vanishing after re-calculating the applied doses on the basis of NP surfaces [65].

Differences in toxicity may also be related to differences in NP uptake, which can be size dependent as well $[42,43]$. Via confocal microscopy and flow cytometry we could confirm that indeed the uptake of our NP was size and also cell-type dependent. Different uptake rates correlated very well with different toxicities. For instance, THP-1 macrophages and A549, which show the strongest toxicity, are taking up higher amounts of $\mathrm{SiO}_{2} \mathrm{NP}$ compared to $\mathrm{HaCaT}$ and NRK$52 \mathrm{E}$ cells. The $200 \mathrm{~nm} \mathrm{SiO}{ }_{2} \mathrm{NP}$, which were non-toxic, hardly entered the cells within $2 \mathrm{~h}$. Thus, the $\mathrm{SiO}_{2}$ uptake was not only dependent on NP size but also on the cell line. In another study, Nabeshi et al. also could correlate uptake and toxicity for different amorphous silica NP in Langerhans cells [54]. However, this study assessed only one cell type while in our study four different cell lines were compared.

In our study $\mathrm{SiO}_{2} \mathrm{NP}$ were taken up into the cytoplasm. We did not detect any $\mathrm{SiO}_{2} \mathrm{NP}$ in the cell nuclei. The majority of other studies also confirm that $\mathrm{SiO}_{2} \mathrm{NP}$ do not enter the cell nuclei, also for A549 cells $[28,66,67]$. Very rarely it has been published that $\mathrm{SiO}_{2} \mathrm{NP}$ can enter the nucleus. $\mathrm{Zhu}$ et al. report nuclear localization for $50 \mathrm{~nm} \mathrm{SiO}{ }_{2}$ in HeLa cells [43]. Eventually, this may be related to different surface modifications of the silica [30].

The confocal images in our study confirm that the $\mathrm{SiO}_{2} \mathrm{NP}$ were rather distinctly localized in structures, most likely vesicles, in the cytosol. We could demonstrate that at least a part of them are lysosomes. Co-localization between $\mathrm{SiO}_{2} \mathrm{NP}$ and lysosomes could not be observed at early time points, only after $24 \mathrm{~h}$, suggesting that $\mathrm{NP}$ are taken up into endocytotic compartments, which are then trafficked and only later fused with lysosomal compartments [68]. Similar kinetics were reported by others. Rawi et al. investigated the uptake and intracellular localization of submicron and nano-sized $\mathrm{SiO}_{2}$ particles in HeLa cells 
and proved that $\mathrm{SiO}_{2} \mathrm{NP}(70 \mathrm{~nm})$ are co-localized with lysosomes after $24 \mathrm{~h}$. However, larger particles, ie $200 \mathrm{~nm}$ and $500 \mathrm{~nm}$, show less lysosomal localization [69]. A possible explanation for this sizedependent localization of NP in lysosomes could be a size-dependent preference for clathrin versus caveolin mediated endocytosis [70].

Clathrin-mediated endocytosis (CME) is a receptor-mediated endocytosis and is involved in uptake of many nutrients such as LDL or iron-carrying transferrin. Specific receptors identify substrate and cargo them into "clathrin coated pits", forming 60-200 nm vesicles that later enter the endosomal pathway and fuse with lysosomes [70]. Caveolae are a subtype of lift rafts and typically cluster in cholesterol-rich regions of plasma membrane, forming flask-shaped invaginations of 50-100 $\mathrm{nm}$ [71]. They are highly abundant in endothelial cells. In contrast to clathrin- coated pits caveolin remains attached to the vesicles and at least some of the vesicles seem to escape the fusion with lysosomes [72]. In general, the caveolin-mediated endocytosis is favored for nanomedicine because NP can escape lysosomal degradation via this pathway.

Here we used Chlorpromazine and a potassium-depleted buffer, two well-known inhibitors to block the clathrin-mediated pathway. Genistein and filipin were used to block the caveolin-mediated pathway. However, sometimes these inhibitors are not as selective and may as well block other uptake pathways [71]. We analyzed the efficiency of these inhibitors in our cell systems by using transferrin and lactosylceramide (LacCer) as substrates [70]. Chlorpromazine could strongly inhibit the uptake of transferrin in THP-1 macrophages but not in A549 cells, which is in contrast to results from another study, where it could block clathrin-mediated endocytosis in A549 cells by $90 \%$ [73]. Here, the effects of chlorpromazine appear to be cell type dependent. However, potassium-depletion worked very well for both cell types. By inhibiting clathrin-mediated endocytosis we could show that this pathway is involved in the uptake of all sizes of $\mathrm{SiO}_{2} \mathrm{NP}$ in both cell lines. In literature there is evidence that a broad size range of $\mathrm{SiO}_{2}$ particles $(50 \mathrm{~nm}-600 \mathrm{~nm})$ can be taken up by clathrin-mediated endocytosis in different cell types $[17,27,40,43]$. The caveolin-mediated pathway seems to contribute only for the 60 and $200 \mathrm{~nm} \mathrm{SiO} 2 \mathrm{NP}$. Clearly it was not involved in uptake of the $15 \mathrm{~nm}$ NP. In contrast, inhibitors against the clathrin endocytosis had a stronger effect on the uptake of the 60 and $200 \mathrm{~nm}$ particles compared to inhibitors of the caveolin endocytosis. This suggests that for 60 and $200 \mathrm{~nm} \mathrm{SiO}{ }_{2} \mathrm{NP}$ the clathrin-mediated endocytosis is the main uptake route, although a part of the NP may enter the cells via the caveolin pathway. However, for $15 \mathrm{~nm} \mathrm{SiO}{ }_{2} \mathrm{NP}$ other uptake mechanisms should exist, which may be clathrin- and caveolin- independent.

So far uptake of $\mathrm{SiO}_{2} \mathrm{NP}$ smaller than $50 \mathrm{~nm}$ hardly has been analyzed. In one study $10 \mathrm{~nm} \mathrm{SiO}{ }_{2} \mathrm{NP}$ were shown to taken up via both, clathrin and caveolin-mediated endocytosis in ovarian cancer cells [74]. Another study analyzed Sicastar Red-SiO 2 NP (30, 70 and $300 \mathrm{~nm})$ in NCI-H441 and ISO-HAS- 1 cells and found a clathrin- and caveolinindependent uptake mechanism [25,41]. The extent of $\mathrm{SiO}_{2}$ uptake via clathrin-mediated pathway seems to change with size. Chlorpromazine was more effective in inhibiting the uptake of $200 \mathrm{~nm}$ polystyrene NP compared to $40 \mathrm{~nm}$ in A549 cells [73]. We observe similar results. Also in our study chlorpromazine was more effective towards 60 and 200 $\mathrm{nm} \mathrm{SiO}$.

We also observed differences in the uptake of the $60 \mathrm{~nm} \mathrm{SiO}$ between A549 cells and THP-1 macrophages. For the uptake of polystyrene NP cell-type dependent differences in uptake mechanisms already have been described for HeLa, A549 and 1321N1 cells [73] Similar studies with $\mathrm{SiO}_{2} \mathrm{NP}$ are not published.

It is well known that NP in biological fluids are covered by a socalled "protein corona". We also detect protein adsorption to our $\mathrm{SiO}_{2}$ $\mathrm{NP}$, which in turn caused massive agglomeration in serum containing media, especially for the 15 and $60 \mathrm{~nm} \mathrm{SiO}$. Moreover, in serum containing medium the uptake of $\mathrm{SiO}_{2} \mathrm{NP}$ is drastically reduced, which was also detected in other studies $[45,46]$. In these studies it has been observed that in the presence of serum $\mathrm{SiO}_{2} \mathrm{NP}$ show a reduced adhesion to the cell membrane, leading to a reduced cellular uptake. This has been confirmed here. Concerning the uptake mechanisms we focused our comparison between serum containing and serum-free conditions on the $200 \mathrm{~nm} \mathrm{SiO}$, as the 15 and $60 \mathrm{~nm} \mathrm{SiO}$, were strongly agglomerated in the presence of serum. Our data indicate that the uptake mechanisms for $200 \mathrm{~nm} \mathrm{SiO}{ }_{2}$ seem to be more specific in the presence of serum. The inhibitor, in particular chlorpromazine, had a much stronger inhibitory effect in the presence of serum. The $200 \mathrm{~nm} \mathrm{SiO} \mathrm{NP}_{2}$ seem to be nearly exclusively taken up by the clathrin pathway under serum containing conditions. Eventually the presence of proteins on the surface of the NP is supporting the receptor-mediated recognition.

Furthermore it should be noted that also the cytotoxicity is changing significantly in the presence of serum as in the presence of serum no toxicity is observed. Eventually in the absence of serum $\mathrm{SiO}_{2}$ NP may also penetrate the cells directly without prior interaction to specific receptors as they are highly protein adsorptive. This may cause cell death. It would be highly interesting to compare also the uptake mechanisms for smaller sizes of $\mathrm{SiO}_{2} \mathrm{NP}$ in the presence and absence of serum. For that purpose one would require $\mathrm{SiO}_{2} \mathrm{NP}$ that do not agglomerate in the presence of serum.

In summary, our data confirm that the uptake mechanisms for $\mathrm{SiO}_{2} \mathrm{NP}$ are strongly dependent on the NP sizes but also on the cell lines used in the study. In particular for the smaller particles $(15 \mathrm{~nm}$ diameter) we find evidence that also other pathways being independent of clathrin and caveolin strongly contribute to the uptake, at least under serum free conditions. Clathrin mediated endocytosis seems to contribute to the uptake of all sizes used in this study while caveolin mediated endocytosis plays only a minor role and is involved only for the uptake of 60 and $200 \mathrm{~nm} \mathrm{SiO}{ }_{2}$ NP. In future studies it might be interesting to design special types of $\mathrm{SiO}_{2} \mathrm{NP}$ by using different surface coatings, which are stable in the presence of serum and which are taken up more specifically via caveolin-mediated endocytosis, which may be superior for medical applications.

\section{Conclusion}

Here we analyse the uptake and the uptake mechanisms of $\mathrm{SiO}_{2}$ $\mathrm{NP}$ using a well-suited fluorescently labeled core-shell $\mathrm{SiO}_{2} \mathrm{NP}$ system to prevent dye-leakage and alteration of the NP surface properties via dye attachment. The fluorescently labeled core-shell $\mathrm{SiO}_{2} \mathrm{NP}$ have been specifically synthesized for the purpose of this study. We use three different sizes (i.e 15, 60 and $200 \mathrm{~nm}$ ) and four different cell lines representing different uptake routes or important secondary target organs, i.e a lung related cell line (A549), a skin related cell line (HaCaT), kidney cells (NRK-52E) and macrophage like cells (THP-1 derived). We observe a size dependent cytotoxicity in all four cell lines in serum free conditions, which correlated well with different uptake into the four cell types. Clathrin-mediated endocytosis was involved in uptake of all sizes of $\mathrm{SiO}_{2}$ particles in THP-1 macrophages and in A549 cells. Caveolin-mediated endocytosis contributed to the uptake of 60 and $200 \mathrm{~nm} \mathrm{SiO} 2$ NP in THP-1 macrophages but only to uptake of 200 
$\mathrm{nm} \mathrm{SiO}{ }_{2} \mathrm{NP}$ in A549. Interestingly for the $15 \mathrm{~nm} \mathrm{SiO}$ the caveolinmediated endocytosis seems not be involved. Thus, we find evidence that another pathway, which is clathrin- and caveolin- independent, could be involved in the uptake of the $15 \mathrm{~nm} \mathrm{SiO}_{2} \mathrm{NP}$.

In the presence of serum, all sizes of $\mathrm{SiO}_{2} \mathrm{NP}$ become non toxic and the uptake in general is significantly reduced. Furthermore the uptake mechanisms may change. For the $200 \mathrm{~nm} \mathrm{SiO}{ }_{2} \mathrm{NP}$ the uptake seems to be more specific, now mostly exclusively via the clathrin-mediated endocytosis.

In summary, this study demonstrates size- and cell type dependent differences in $\mathrm{SiO}_{2} \mathrm{NP}$ uptake and in uptake mechanisms, which could be relevant for potential use of $\mathrm{SiO}_{2} \mathrm{NP}$ as a drug delivery system in the medical field.

\section{Acknowledgement}

The authors acknowledge funding from BfR and TU. I-Lun Hsiao also thanks DAAD and the Ministry of Science and Technology Taiwan (MOST) for financial support.

\section{References}

1. Project on Emerging Nanotechnologies. Nanotechnology consumer products inventory analysis ; updated 2013 October. Accessed May 20, 2014.

2. Hansen SF, Michelson ES, Kamper A, Borling P, Stuer-Lauridsen F, et al (2008) Categorization framework to aid exposure assessment of nanomaterials in consumer products. Ecotoxicology 17: 438-447.

3. Athinarayanan J, Periasamy VS, Alsaif MA, Al-Warthan AA, Alshatwi AA (2014) Presence of nanosilica (E551) in commercial food products: TNF-mediated oxidative stress and altered cell cycle progression in human lung fibroblast cells. Cell Biol Toxicol 30: 89-100.

4. Biju V (2014) Chemical modifications and bioconjugate reactions of nanomaterials for sensing, imaging, drug delivery and therapy. Chem Soc Rev 43: 744-764

5. Yang PP, Gai SL, Lin J (2012) Functionalized mesoporous silica materials for controlled drug delivery. Chem Soc Rev 41: 3679-3698.

6. Tallury P, Payton K, Santra S (2008) Silica-based multimodal/multifunctional nanoparticles for bioimaging and biosensing applications. Nanomedicine 3 : 579-592.

7. Oberdorster G, Oberdorster E, Oberdorster J (2005) Nanotoxicology: An emerging discipline evolving from studies of ultrafine particles. Environ Health Perspect 113: 823-839.

8. Landsiedel R, Ma-Hock L, Hofmann T, Wiemann M, Strauss V, et al. (2014) Application of short-term inhalation studies to assess the inhalation toxicity of nanomaterials. Part Fibre Toxicol11:16.

9. Arts JH, Muijser H, Duistermaat E, Junker K, Kuper CF (2007) Five-day inhalation toxicity study of three types of synthetic amorphous silicas in Wista rats and post-exposure evaluations for up to 3 months. Food Chem Toxicol 45 : 1856-1867.

10. Park EJ, Roh J, Kim Y, Choi K (2011) A single instillation of amorphous silica nanoparticles induced inflammatory responses and tissue damage until Day 28 after exposure. J Health Sci 57: 60-71.

11. Hirai T, Yoshikawa T, Nabeshi H, Yoshida T, Akase T, et al. (2012) Derma absorption of amorphous nanosilica particles after topical exposure for three days. Pharmazie 67: 742-743.

12. Rancan F, Gao Q, Graf C, Troppens S, Hadam S, et al. (2012) Skin penetration and cellular uptake of amorphous silica nanoparticles with variable size, surface functionalization, and colloidal stability. ACS Nano 6: 6829-6842.

13. van der Zande M, Vandebriel RJ, Groot MJ, Kramer E, Herrera Rivera ZE, et al. (2014) Sub-chronic toxicity study in rats orally exposed to nanostructured silica. Part Fibre Toxicol 11:8.

14. Sakai N, Takakura M, Imamura H, Sugimoto M, Matsui $Y$, et al. (2012) Wholebody distribution of C-14-labeled silica nanoparticles and submicron particles after intravenous injection into Mice. J Nanopart Res 14: 849.

15. Yu Y, Li Y, Wang W, Jin M, Du Z, et al. (2013) Acute toxicity of amorphous silica nanoparticles in intravenously exposed ICR mice. PLoS One 8: e61346.
16. Lu X, Qian JC, Zhou HJ, Gan Q, Tang W, et al. (2011) In vitro cytotoxicity and induction of apoptosis by silica nanoparticles in human HepG2 hepatoma cells Int J Nanomed 6: 1889-1901.

17. Passagne I, Morille M, Rousset M, Pujalte I, L'Azou B (2012) Implication of oxidative stress in size-dependent toxicity of silica nanoparticles in kidney cells. Toxicology 299: 112-124

18. Skuland T, Ovrevik J, Lag M, Refsnes M (2014) Role of size and surface area for pro-inflammatory responses to silica nanoparticles in epithelial lung cells: Importance of exposure conditions. Toxicol Vitro 28: 146-155.

19. Park M, Lynch I, Ramirez-Garcia S, Dawson KA, de la Fonteyneet L, et al (2011) In vitro evaluation of cytotoxic and inflammatory properties of silica nanoparticles of different sizes in murine RAW 264.7 macrophages. J Nanopart Res 13: 6775-6787.

20. Duan JC, Yu YB, Li Y, Yu Y, Li Y, et al. (2013) Toxic effect of silica nanoparticles on endothelial cells through DNA damage response via Chk1-dependent G2/M checkpoint. PLoS One 8: e62087.

21. Ahmad J, Ahamed M, Akhtar MJ, Alrokayan SA, Siddiqui MA, et al. (2012) Apoptosis induction by silica nanoparticles mediated through reactive oxygen species in human liver cell line HepG2. Toxicol Appl Pharmacol 259: 160-168.

22. Mohamed BM, Verma NK, Prina-Mello A, Williams Y, Davies AM, et al. (2011) Activation of stress-related signalling pathway in human cells upon $\mathrm{SiO} 2$ nanoparticles exposure as an early indicator of cytotoxicity. J Nanobiotechnol 9: 29 .

23. Li Y, Sun L, Jin MH, Du Z, Liu X, et al. (2011) Size-dependent cytotoxicity of amorphous silica nanoparticles in human hepatoma HepG2 cells. Toxicol Vitro 25: $1343-1352$

24. Liang H, Jin C, Tang Y, Wang F, Ma C, et al. (2014) Cytotoxicity of silica nanoparticles on HaCaT cells. J Appl Toxicol 34: 367-372.

25. Kasper J, Hermanns MI, Bantz C, Koshkina O, Lang T, et al. (2013) Interactions of silica nanoparticles with lung epithelial cells and the association to flotillins. Arch Toxicol 87: 1053-1065.

26. McCarthy J, Inkielewicz-Stepniak I, Corbalan JJ, Radomski MW (2012) Mechanisms of toxicity of amorphous silica nanoparticles on human lung submucosal cells in vitro: protective effects of Fisetin. Chem Res Toxicol 25: 2227-2235.

27. Blechinger J, Bauer AT, Torrano AA, Gorzelanny C, Bräuchle C, et al. (2013) Uptake kinetics and nanotoxicity of silica nanoparticles are cell type dependent Small 9: 3970-3980.

28. Mu QS, Hondow NS, Krzeminski L, Brown AP, Jeuken LJ, et al. (2012) Mechanism of cellular uptake of genotoxic silica nanoparticles. Part Fibre Toxicol 9: 29.

29. Yu T, Malugin A, Ghandehari H (2011) Impact of silica nanoparticle design on cellular toxicity and hemolytic activity. ACS Nano 5: 5717-5728.

30. Nabeshi H, Yoshikawa T, Arimori A, Yoshida T, Tochigi S, et al. (2011) Effect of surface properties of silica nanoparticles on their cytotoxicity and cellular distribution in murine macrophages. Nanoscale Res Lett 6: 93.

31. Napierska D, Thomassen LCJ, Lison D, Martens JA, Hoet PH (2010) The nanosilica hazard: another variable entity. Part Fibre Toxicol 7: 39.

32. Marzaioli V, Aguilar-Pimentel JA, Weichenmeier I, Luxenhofer G, Wiemann $M$, et al. (2014) Surface modifications of silica nanoparticles are crucial for their inert versus proinflammatory and immunomodulatory properties. Int J Nanomed 9: 2815-2832.

33. Sayes CM, Reed KL, Warheit DB (2007) Assessing toxicity of fine and nanoparticles: Comparing in vitro measurements to in vivo pulmonary toxicity profiles. Toxicol Sci 97: 163-180.

34. Lee S, Kim MS, Lee D, Kwon TK, Khang D, et al. (2013) The comparative immunotoxicity of mesoporous silica nanoparticles and colloidal silica nanoparticles in mice. Int J Nanomed 8: 147-158.

35. Kennedy IM, Wilson D, Barakat AI (2009) Uptake and inflammatory effects of nanoparticles in a human vascular endothelial cell line. Res Rep Health Eff Inst136: 3-32.

36. Wang JD, Teng ZG, Tian Y, Fang T, Ma J, et al. (2013) Increasing cellular uptake of mesoporous silica nanoparticles in human embryonic kidney cell line 293T cells by using Lipofectamine 2000. J Biomed Nanotechnol 9: 1882-1890. 
Citation: Hsiao I, Gramatke AM, Joksimovic R, Sokolowski M, Gradzielski M, et al. (2014) Size and Cell Type Dependent Uptake of Silica Nanoparticles. J Nanomed Nanotechnol 5: 248. doi: 10.4172/2157-7439.1000248

Page 10 of 10

37. Lu F, Wu SH, Hung Y, Mou CY (2009) Size effect on cell uptake in wellsuspended, uniform mesoporous silica nanoparticles. Small 5: 1408-1413.

38. Gliga AR, Skoglund S, Wallinder IO, Fadeel B, Karlsson HL (2014) Sizedependent cytotoxicity of silver nanoparticles in human lung cells: the role of cellular uptake, agglomeration and Ag release. Part Fibre Toxicol 11: 11

39. dos Santos T, Varela J, Lynch I, Salvati A, Dawson KA (2011) Quantitative assessment of the comparative nanoparticle-uptake efficiency of a range of cell lines. Small 7: 3341-3349.

40. Hu L, Mao Z, Zhang Y, Gao C (2011) Influences of size of silica particles on the cellular endocytosis, exocytosis and cell activity of HepG2 cells. J Nanoscience Lett 1: 1-16.

41. Kasper J, Hermanns MI, Bantz C, Utech S, Koshkina O, et al. (2013) Flotillininvolved uptake, of silica nanoparticles and responses of an alveolar-capillary barrier in vitro. Eur J Pharm Biopharm 84: 275-287.

42. Shapero K, Fenaroli F, Lynch I, Cottell DC, Salvati A, et al. (2011) Time and space resolved uptake study of silica nanoparticles by human cells. Mol Biosyst 7: 371-378.

43. Zhu J, Liao L, Zhu LN, Zhang P, Guo K, et al. (2013) Size-dependent cellular uptake efficiency, mechanism, and cytotoxicity of silica nanoparticles toward HeLa cells. Talanta 107: 408-415.

44. Vranic S, Boggetto N, Contremoulins V, Mornet S, Reinhardt N, et al. (2013) Deciphering the mechanisms of cellular uptake of engineered nanoparticles by accurate evaluation of internalization using imaging flow cytometry. Part Fibre Toxicol 10: 2 .

45. Lesniak A, Fenaroli F, Monopoli MR, Åberg C, Dawson KA, et al. (2012) Effects of the presence or absence of a protein corona on silica nanoparticle uptake and impact on cells. ACS Nano 6: 5845-5857.

46. Lesniak A, Salvati A, Santos-Martinez MJ, Radomski MW, Dawson KA, et al. (2013) Nanoparticle adhesion to the cell membrane and its effect on nanoparticle uptake efficiency. J Am Chem Soc 135: 1438-1444.

47. Kendall M, Ding P, Kendall K (2011) Particle and nanoparticle interactions with fibrinogen: the importance of aggregation in nanotoxicology. Nanotoxicology 5. $55-65$

48. Turci F, Ghibaudi E, Colonna M, Boscolo B, Fenoglio I, et al. (2010) An integrated approach to the study of the interaction between proteins and nanoparticles. Langmuir 26: 8336-8346.

49. Yan Y, Gause KT, Kamphuis MM, Ang CS, O'Brien-Simpson NM, et al. (2013) Differential roles of the protein corona in the cellular uptake of nanoporous polymer particles by monocyte and macrophage cell lines. ACS Nano 7: 1096010970.

50. Lunov O, Syrovets T, Loos C, Beil J, Delacher M, et al. (2012) Differentia uptake of functionalized polystyrene nanoparticles by human macrophages and monocytic cells. ACS Nano 5: 1657-1669.

51. Salvati A, Aberg C, dos Santos T, Varela J, Pinto P, et al. (2011) Experimental and theoretical comparison of intracellular import of polymeric nanoparticles and small molecules: toward models of uptake kinetics. Nanomed-Nanotechnol Biol Med 7: 818-826.

52. Joksimovic R, Altin B, Mehta SK, Gradzielski M (2013) Synthesis of silica nanoparticles covered with silver beads. J Nanosci Nanotechnol 13: 67736781.

53. Kahlert S, Zundorf G, Reiser G (2005) Glutamate-mediated influx of extracellular $\mathrm{Ca}^{2+}$ is coupled with reactive oxygen species generation in cultured hippocampal neurons but not in astrocytes. J Neurosci Res 79: 262-271.

54. Nabeshi H, Yoshikawa T, Matsuyama K, Nakazato Y, Arimori A, et al. (2010) Size-dependent cytotoxic effects of amorphous silica nanoparticles on Langerhans cells. Pharmazie 65: 199-201.

55. Napierska D, Thomassen LCJ, Rabolli V, Lison D, Gonzalez L, et al. (2009) Size-dependent cytotoxicity of monodisperse silica nanoparticles in human endothelial cells. Small 5: 846-853.

56. Lin WS, Huang YW, Zhou XD, Ma YF (2006) In vitro toxicity of silica nanoparticles in human lung cancer cells. Toxicol Appl Pharmacol 217: 252-259.

57. Ye YY, Liu JW, Chen MC, Sun LJ, Lan MB (2010) In vitro toxicity of silica nanoparticles in myocardial cells. Environ Toxicol Pharmacol 29: 131-137.

58. Nel A, Xia T, Madler L, Li N (2006) Toxic potential of materials at the nanolevel. Science 311: 622-627.
59. Kipen HM, Laskin DL (2005) Smaller is not always better: nanotechnology yields nanotoxicology. Am J Physiol-Lung Cell Mol Physiol. 289: L696-L697.

60. Shang Y, Zhu T, Li Y, Zhao J (2009) Size-dependent hydroxyl radicals generation induced by $\mathrm{SiO}_{2}$ ultra-fine particles: The role of surface iron. Sci China Ser B. 52: 1033-1041.

61. Kroll A, Dierker C, Rommel C, Hahn D, Wohlleben W, et al. (2011) Cytotoxicity screening of 23 engineered nanomaterials using a test matrix of ten cell lines and three different assays. Part Fibre Toxicol 8: 9 .

62. Chang JS, Chang KLB, Hwang DF, Kong ZL (2007) In vitro cytotoxicitiy of silica nanoparticles at high concentrations strongly depends on the metabolic activity type of the cell line. Environ Sci Technol 41: 2064-2068.

63. Lanone S, Rogerieux F, Geys J, Dupont A, Maillot-Marechal E, et al. (2009) Comparative toxicity of 24 manufactured nanoparticles in human alveolar epithelial and macrophage cell lines. Part Fibre Toxicol 6: 14

64. Hamilton RF, Thakur SA, Holian A (2008) Silica binding and toxicity in alveolar macrophages. Free Radic Biol Med 44: 1246-1258.

65. Guthrie GD, Heaney PJ (1995) Mineralogical characteristics of silica polymorphs in relation to their biological activities. Scand J Work Environ Health 21: 5-8.

66. Jin YH, Kannan S, Wu M, Zhao JX (2007) Toxicity of luminescent silica nanoparticles to living cells. Chem Res Toxicol 20: 1126-1133.

67. Stayton I, Winiarz J, Shannon K, Ma YF (2009) Study of uptake and loss of silica nanoparticles in living human lung epithelial cells at single cell level. Anal Bioanal Chem 394: 1595-1608.

68. Huang DM, Hung Y, Ko BS, Hsu SC, Chen WH, et al. (2005) Highly efficient cellular labeling of mesoporous nanoparticles in human mesenchymal stem cells: implication for stem cell tracking. Faseb J 19: 2014-2016.

69. Al-Rawi M, Diabate S, Weiss C (2011) Uptake and intracellular localization of submicron and nano-sized $\mathrm{SiO}_{2}$ particles in HeLa cells. Arch Toxicol 85: 813826

70. Rejman J, Oberle V, Zuhorn IS, Hoekstra D (2004) Size-dependent internalization of particles via the pathways of clathrin-and caveolae-mediated endocytosis. Biochem J 377:159-169.

71. Sahay G, Alakhova DY, Kabanov AV (2010) Endocytosis of nanomedicines. J Control Release 145: 182-195.

72. Kiss AL, Botos E (2009) Endocytosis via caveolae: alternative pathway with distinct cellular compartments to avoid lysosomal degradation? J Cell Mol Med 13: $1228-1237$

73. dos Santos T, Varela J, Lynch I, Salvati A, Dawson KA (2011) Effects of transport inhibitors on the cellular uptake of carboxylated polystyrene nanoparticles in different cell lines. PLoS One 6: e24438.

74. Ekkapongpisit M, Giovia A, Follo C, Caputo G, Isidoro C (2012) Biocompatibility, endocytosis, and intracellular trafficking of mesoporous silica and polystyrene nanoparticles in ovarian cancer cells: effects of size and surface charge groups. Int J Nanomed 7: 4147-4158. 